Jurnal Pemberdayaan: Publikasi Hasil Pengabdian kepada Masyarakat

Vol. 2, No. 3, Desember 2018, Hal. 441-448

ISSN: 2580-2569; e-ISSN: XXXX-XXXX

DOI:

\title{
PEMANFAATAN SAMPAH PLASTIK UNTUK PEMBERDAYAAN TANAMAN TOGA DALAM PROGRAM PENGHIJAUAN LINGKUNGAN SINGOJAYAN
}

\author{
Fitri Merawati ${ }^{1}$ dan Bidayatun Nafi' ${ }^{2}{ }^{2}$ \\ Universitas Ahmad Dahlan ${ }^{1,2}$, \\ Jalan Ring Road Selatan, Tamana, Bantul, Yogyakarta \\ fitri.merawati@pbsi.uad.ac.id ${ }^{1}$
}

\begin{abstract}
ABSTRAK
Beberapa permasalahan yang ditemukan di kampung Singojayan adalah 1) banyak lahan yang belum digunakan secara optimal, 2) pengetahuan masyarakat dalam pemanfaatan lahan untuk penghijauan masih minim, 3) engetahuan masyarakat dalam memanfaatkan sampah plastik untuk media tanam masih kurang, dan 4) pengetahuan masyarakat dalam pemanfaatan lahan yang sempit untuk penghijauan masih kurang. Untuk mencapai tujuan yang diharapkan, program kerja dilakukan dengan pemberdayaan masyarakat melalui penyuluhan tentang tanaman toga dan praktik langsung bersama warga. Plastik makanan yang dipilih sebagian untuk media tanam juga bermaksud untuk memberikan kesadaran warga kampung Singojayan bahwa hal yang sering kita buang dapat memberikan manfaat untuk media tanaman yang menyimpan banyak oksigen. Tanaman obat yang ditanam seperti jenis tanaman yang dapat digunakan dalam kehidupan sehari-hari dan adapula jenis tanaman obat tetapi dapat untuk menghias halaman rumah sebagai pelengkap obat-obatan keluarga yang bersifat tradisional. Dampak adanya program ini adalah masyarakat dapat memanfaatkan barang-barang di sekelilingnya yang dianggap tidak bermanfaat menjadi memiliki nilai guna dan ekonomis.
\end{abstract}

Kata kunci: toga, plastik makanan, Singojayan, penghijauan, pemberdayaan

\begin{abstract}
Some of the problems found in Singojayan village are 1) a lot of land that has not been used optimally, 2) community knowledge in the use of land for reforestation is still minimal, 3) public knowledge in utilizing plastic waste for planting media is still lacking, and 4) community knowledge in narrow land use for reforestation is still lacking. To achieve the expected goals, work program conducted by community empowerment through counseling about toga plants and direct practice with residents. Food plastic that was partially chosen for the planting media also intends to raise awareness among Singojayan villagers that the things we often dispose can provide benefits for media plants that store a lot of oxygen. Planted medicinal plants such as the types of plants that can be used in daily life and there are also types of medicinal plants but can be used to decorate the home page as a complement to traditional family medicines. The impact of this program is that the community can utilize the goods around it which are considered not useful to have useful and economic value.
\end{abstract}

Keywords: toga, plastic food, Singojayan, greening, empowerment

\section{PENDAHULUAN}

Singojayan merupakan salah satu kampung di kelurahan Pakuncen Kecamatan Wirobrajan. Singojayan berada di RW 01 dan terdir dari 6 RT. Akses jalan Singojayan cukup mudah dilalui oleh transportasi darat baik roda dua maupun roda empat, namun ada beberapa jalan yang tidak dapat di lewati dua mobil artinya jalan hanya bisa 1 mobil. Kondisi air yang 
berasal dari PDAM juga cukup memadai. Beberapa permasalahan yang ditemukan di kampung Singojayan adalah 1) banyak lahan yang belum digunakan secara optimal, 2) pengetahuan masyarakat dalam pemanfaatan lahan untuk penghijauan masih minim, 3) engetahuan masyarakat dalam memanfaatkan sampah plastik untuk media tanam masih kurang, dan 4) pengetahuan masyarakat dalam pemanfaatan lahan yang sempit untuk penghijauan masih kurang. Berdasarkan data Kementerian Lingkungan Hidup (KLH), setiap hari penduduk Indonesia menghasilkan $0,8 \mathrm{~kg}$ sampah per orang atau secara total sebanyak 189 ribu ton sampah/hari. Dari jumlah tersebut $15 \%$ berupa sampah plastik atau sejumlah 28,4 ribu ton sampah plastik/hari. Semakin meningkatnya sampah ini akan menjadi masalah serius bila tidak dicari penyelesaiannya. Penanganan sampah plastik yang populer selama ini adalah dengan 3R (reuse, reduce, recycle).

Tumbuhan di bumi memiliki peran penting untuk menangani krisis lingkungan, terutama di daerah perkotaan. Salah satu tanaman yang dapat dilestarikan adalah toga (tanaman obat keluarga). Tanaman obat dipercaya mempunyai khasiat yang lebih ampuh daripada obat-obat dokter. Namun, karena perkembangan zaman dan semakin meningkatnya pengetahuan manusia tentang farmakologi dan ilmu kedokteran, banyak masyarakat yang beralih ke obatobatan dokter karena lebih mempercayai obat- obatan kimia yang telah teruji khasiatnya secara laboratorium, dibandingkan dengan obat tradisional yang banyak belum bisa dibuktikan secara laboratorium.

Berdasarkan permasalahan tersebut, maka ditetapkan tujuan program pengabdian melalui Kuliah Kerja Nyata ini adalah untuk memberdayakan masyarakat kampung Singojayan dalam kepedulianterhadap lingkungan, khususnya pemanfaatan barang-barang yang dianggap sudah tidak memiliki nilai guna.

\section{METODE PELAKSANAAN}

Tukiman dalam artikelnya yang berjudul "Pemanfaatan Tanaman Obat Keluarga (TOGA) untuk Kesehatan Keluarga" menyebutkan bahwa ada beberpa kriteria tanaman obat keluarga yaitu a. jenis tanaman disebutkan dalam buku pemanfaatan tanaman obat, b. jenis tanaman yang lazim digunakan sebagai obat didaerah pemukiman, dan c. jenis tanaman yang dapat tumbuh dan hidup dengan baik di daerah pemukiman.

Menteri Pertanian, Menteri Penerangan, Menteri RISTEK dan Menteri PPLH melalui artikel Hadi (2009) berjudul "Konservasi Sumberdaya Alam dan Pengelolaan Lingkungan" menyatakan bahwa titik tolak konservasi sumberdaya alam hayati bersumber dari strategi 
konservasi dunia yang pada tahun 1980 diumumkan di Indonesia bersama 30 negara lain, salah satunya adalah tentang perlindungan sistem penyangga kehidupan perlindungan proses ekologis sebagai sistem penyangga kehidupan, karena sistem penyangga kehidupan harus dalam keadaan yang seimbang. Lingkungan asli/alam (sudah dalam keseimbangan yang stabil) dan lingkungan buatan (dalam keadaan tidak stabil) .

Riadi (2015) mengemukakan bahwa sampah platik merupakan bagian dari sampah anorganik yaitu sampah yang dihasilkan drai bahan non hayati baik hasil sintetis, hasil proses pengolahan teknolog, dan hasil tambang

Untuk mencapai tujuan yang diharapkan, pemberdayaan masyarakat melalui penyuluhan tanaman toga dan praktek langsung. Ringkasan metode pelaksanaan beserta jam kerja efektif mahasiswa (JKEM) tersaji pada table I.

Tabel I. Metode, Kegiatan, JKEM dan keterlibatan mahasiswa

\begin{tabular}{|c|l|c|c|}
\hline No & \multicolumn{1}{|c|}{ Kegiatan } & JKEM & Jumlah Mhs \\
\hline 1 & Memberikan sosialisasi tanaman toga. & $1 \times 50 ”$ & 27 \\
\hline 2 & Memberikan sosialisasi pemanfaatan sampah plastik & $1 \times 50 ”$ & 27 \\
\hline 3 & $\begin{array}{l}\text { Melakukan Penanaman Toga bersama warga di Kampung } \\
\text { Singojayan }\end{array}$ & $6 \times 150 "$ & 27 \\
\hline
\end{tabular}

\section{HASIL, PEMBAHASAN, DAMPAK}

Sesuai dengan permasalahan yang dihadapi oleh warga masyarakat kampung Singojayan, sehubungan dengan upaya pengembangan wawasan pengetahuan dan keterampilan pengolahan limbah plastik menjadi produk kreatif, maka program pengabdian masyarakat ini dilakukan dalam bentuk transfer iptek yang dilakukan berupa sosialisasi, pelatihan,dan pendampingan kepada ibu-ibu kampung singojayan yang akan mengolah limbah bungkus plastik yang akan menjadikan media tanam untuk menanam tanaman toga disekitar rumah serta melakukan sosialisasi pentingnya menanam tanaman toga kepada warga kampung singojayan.

Tukiman (2004) dalam artikelnya yang berjudul "Pemanfaatan Tanaman Obat Keluarga (TOGA) untuk Kesehatan Keluarga" menyebutkan bahwa ada beberpa kriteria tanaman obat keluarga yaitu a. jenis tanaman disebutkan dalam buku pemanfaatan tanaman obat, b. jenis tanaman yang lazim digunakan sebagai obat didaerah pemukiman, dan c. jenis tanaman yang dapat tumbuh dan hidup dengan baik di daerah pemukiman. 
Adapun alur pelaksanaan program pengabdian ini dimulai dari, (1) Tahap persiapan, yang terdiri dari tahap: (a) penyiapan bahan administrasi sesuai dengan kebutuhan pelaksanaan sosialisasi, (b) melakukan koordinasi dengan ketua RW/RT/PKK Singojayan (c) menyiapkan materi (d) menyiapkan jadwal sosialisasi menyesuaikan dengan perencanaan kegiatan yang telah terprogram, (2) tahap pelaksanaan, yang terdiri dari: (a) melakukan pengolahan bahan baku (b) diskusi terbatas mengenai pemahaman wawasan dan keterampilan yang sudah mampu dikuasai, (c) melakukan praktek penanaman toga.

Pelaksanaan penanaman toga ini dilakukan di setiap RT yang masing-masing RT kurang lebih $35 \mathrm{KK}$, dalam pelaksanaan ini mahasiswa KKN bekerja sama dengan Badan Lingkungan Hidup (BLH) untuk mendapatkan media berupa kompos dan dalam pencampuran tanah dilakukan bersama dengan warga kampung Singojayan. Program ini dimaksudkan untuk menyadarkan masyarakat bahwa melakukan gerakan penghijauan menanam pohon dalam jumlah banyak, akan semakin tersedia banyak oksigen yang menjadikan udara makin segar, upaya mewujudkan udara segar, akan memberikan banyak manfaat bagi kesehatan semua makhluk hidup. Plastik makanan dipilih sebagian untuk media tanam juga bermaksud untuk memberikan kesadaran warga kampung Singojayan bahwa hal yang sering kita buang dapat memberikan manfaat untuk media tanaman yang menyimpan banyak oksigen.

Selama ini warga beranggapan bahwa tanaman toga selalu dari jenis rimpang-rimpang saja sehingga masyarakat enggan untuk menanam dan merawat tanaman obat tersebut dan menumbuhkan semangat masyarakat untuk menanam tanaman obat. Tanaman obat yang ditanam seperti jenis tanaman yang dapat digunakan dalam kehidupan sehari-hari dan. Manfaat dari tanaman obat keluarga sangat beragam tergantung subjektifitas kita memandangnya. Beberapa manfaat tanaman obat keluarga antara lain sebagai pelengkap obat-obatan keluarga yang bersifat tradisional, bernilai tambah estetika bila di tata dengan apik dan rapi, memberi contoh cara pemanfaatan lingkungan pekarangan, menambah nilai keasrian dan kesejukan halaman pekarangan rumah, tentunya dapat kelola dengan baik dan dapat menghasilkan pendapatan tambahan.

Tabel 2. 10 Jenis tanaman TOGA yang paling banyak ditanam di lokasi penelitian

\begin{tabular}{|l|l|l|}
\hline No & \multicolumn{1}{|c|}{ Nama Tanaman } & \multicolumn{1}{c|}{ Khasiat } \\
\hline 1. & Kunyit & Untuk sakit maag, perut, diare, penurun panas, pendingin perut \\
\hline 2. & Temulawak & Meningkatkan nafsu makan dan menambah stamina \\
\hline 3. & Kencur & Untuk obat batuk \\
\hline 4. & Sereh & Meredakan pilek dan batu,mengatasi sakit perut \\
\hline
\end{tabular}




\begin{tabular}{|l|l|l|}
\hline No & \multicolumn{1}{|c|}{ Nama Tanaman } & \multicolumn{1}{|c|}{ Khasiat } \\
\hline 5. & Bayam Merah & Untuk mengobati Anemia,Melancarkan proses pencernaan \\
\hline 6. & Seledri & Mengobati infeksi kandung kemih,mengontrol tekanan darah \\
\hline 7. & Kenikir & Obat gondongan,maag,bau mulut,menambah nafsu makan \\
\hline 8. & Jahe Merah & Mengatasi nyeri haid,pegal linu,radang tenggorokan,asma \\
\hline 9. & Lidah Buaya & Mengatasi luka,mempercepat penyembuhan luka, \\
\hline 10. & Bayam hijau & Untuk menurunkan tekanan darah,baik untuk pertumbuhan anak \\
\hline 11. & Daun Kemangi & Untuk mengatasi bau badan, \\
\hline 12. & Jahe & Untuk obat batuk \\
\hline 13. & Pepaya & Daun: mencegah kanker buah:melancarkan pencernaaan \\
\hline 14 & Tomat & Menjaga kesehatan kulit,mata,dan menurunkan tekanan daraj \\
\hline 15. & Gambas & Diabetes, Anemia, Migrain \\
\hline 16. & Cabai & Detoksifikasi \\
\hline
\end{tabular}
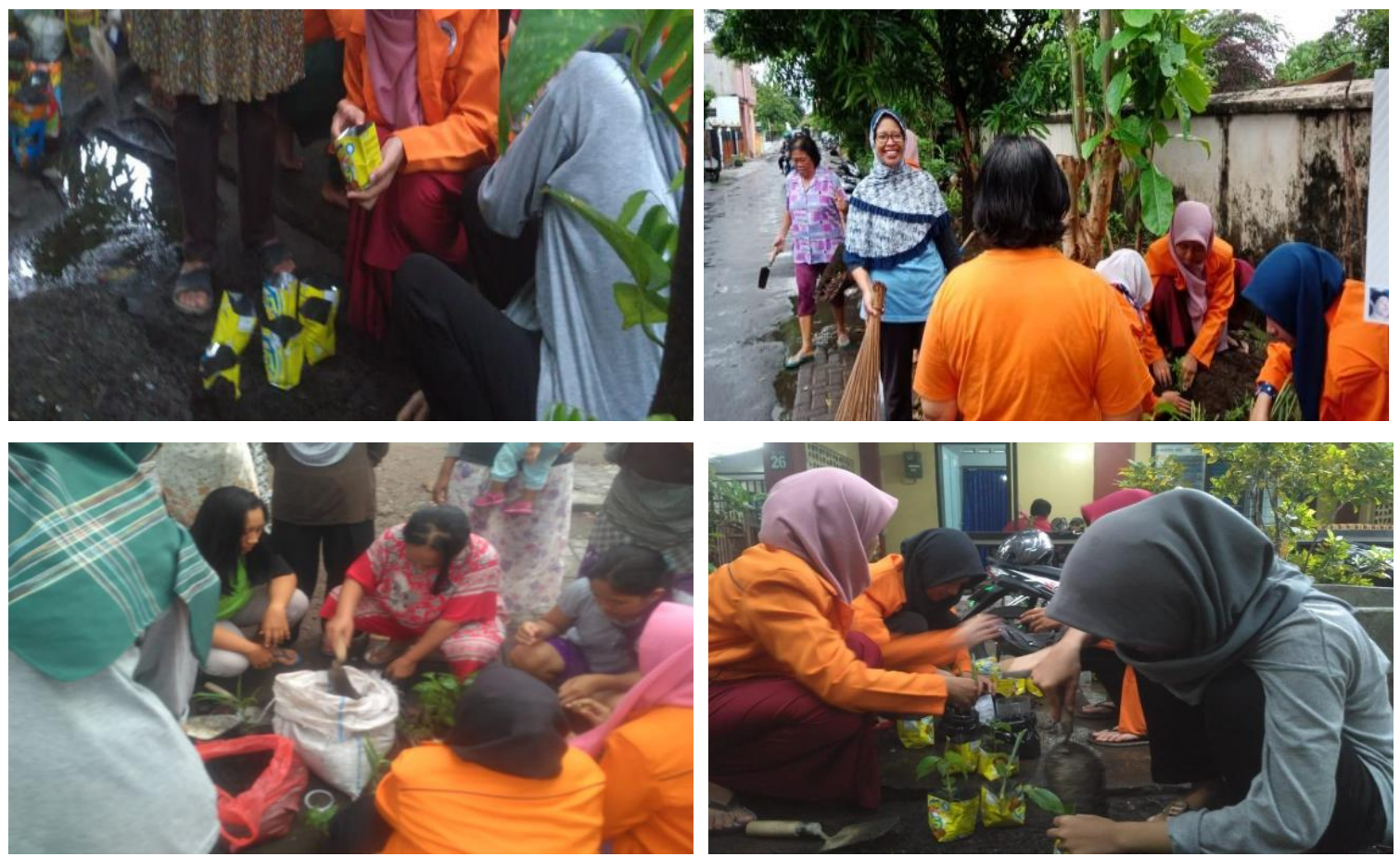

Gambar 1. Praktek pelaksanaan penanaman TOGA

Berdasarkan gambar tersebut terlihat program KKN di kampung Singojayan dapat terlaksana dengan partisipasi masyarakat dalam acara tersebut.sehingga dapat disimpulkan bahwa masyarakat sangat antusias dalam menyambut program kerja yang diadakan guna untuk kelangsungan hidup yang nyaman,indah,bersih . Masyarakat pun mendapatkan manfaat dari tanaman yang ditanaman dalam halaman rumah bahwa untuk melakukan pengobatan yang 
aman dan murah dapat dilakukan serta pemanfaatan sampah plastik yang lama terurai dapat digunakan pula.

Menurut pendapat yang dikemukakan oleh Sudirman, strategi pengelolaan sampah nasional dilakukan berdasarkan Perpres No. 97/2017 tentang Jakstranas Pengelolaan Sampah Rumah Tangga dan Sampah Sejenis Sampah Rumah Tangga. Kebijakan tersebut diterjemahkan pada dua kerja besar yaitu pengurangan sampah dan penanganan sampah. Pengurangan sampah dilakukan dengan tahapan pembatasan sampah, pemanfaatan kembali, dan pendauran ulang. Sedangkan penanganan sampah dijalankan dengan tahapan pemilahan, pengumpulan, pengangkutan, pengolahan, sampai pemrosesan akhir.Pendapat yang dikemukakan oleh sudirman juga menjelaskan bahwa melalui arah kebijakan tersebut, KLHK menargetkan pengurangan sampah sebesar 30\% dan penanganan sampah sebesar $70 \%$ di bawah angka timbulan sampah pada kondisi tanpa ada intervensi kebijakan pengurangan sampai tahun 2025. Hal tersebut didasarkan pada persentase timbulan sampah yang terkelola dan turun selama 5 tahun. Mulai tahun 2015 sampai 2019, persentase timbulan sampah yang terkelola sebesar $80 \%$ dan persentase penurunan sampah mencapai 20\%. Dampak dari kegiataaan ini yaitu, memberikan manfaat kepada masyarakat agar dapat melestarikan tanaman obat sebagai obat tradisional.

Selain itu, manfaat yang diperoleh dalam kegiataan ini untuk meningkatan pengetahuan terhadap jenisjenis tumbuhan obat dapat mengurangi penggunaan obat konvensional, karena tumbuhan obat dapat digunakan sebagai alternatif pengobatan terhadap berbagai macam penyakit. Bertambahnya pengetahuan menghasilkan lebih banyak jenis tumbuhan obat yang dapat digunakan sebagai alternatif jika jenis tumbuhan obat tertentu tidak ditemukan atau tidak tersedia serta pengurangan sampah plastik sehingga dapat mengurangi pencemaran lingkungan dan dapat sebagai media tanam yang mudah didapatkan.

\section{KESIMPULAN}

Berdasarkan penjelasan diatas tanaman toga sangat banyak memilik manfaat untuk meningkatkan penghijauan di kampung singojayan, dan sampah plastik yang selama ini tidak diolah dengan baik dapat digunakan sebagai media tanam tanaman toga . maka dari itu diharapkan masyarakat dapat mempertahankan program kerja yang telah di lakukan. Dan dapat merawat tanaman ini sehingga masyarakat memiliki kepedulian lingkungan selain itu juga diharapkan warga lebih mudah memperoleh tumbuhan obat yang sering dimanfaatkan apabila 
menanam sendiri. Cara memperoleh lainnya, yaitu dengan mengambil sendiri dari alam khusus untuk tumbuhan kategori liar.

\section{DAFTAR PUSTAKA}

Hadi, M. 2009. Konservasi sumberdaya alam dan pengelolaan lingkungan. diakses melalui laman http://eprints.undip.ac.id/1070/1/ILING-II-5-KONSERVASI.pdf. diunduh pada tanggal 19 Desember 2018 pukul 19.30 WIB.

Riadi, M. 2015. Pengertian, jenis, dan dampak sampah. diakses melalui https://www.kajianpustaka.com/2015/02/pengertian-jenis-dan-dampak-sampah.html diunduh pada tanggal 19 Desember 2018 pukul 20.00 WIB.

Tukiman. 2004. Pemanfaatan Tanaman Obat Keluarga (TOGA) untuk Kesehatan Keluarga. diakses melalui http://library.usu.ac.id/download/fkm/fkmtukiman.pdf diunduh pada tanggal 19 Desember 2018 pukul 19.00 WIB.

\section{UCAPAN TERIMA KASIH}

1. Badan Lingkungan Hidup Yogyakarta

2. Masyarakat Kampung Singojayan

3. LPPM Universitas Ahmad Dahlan 
